\title{
Spatiotemporal supraglacial pond and ice cliff changes in the Bhutan-Tibet border region from 2016 to 2018
}

\section{Article}

Cite this article: Taylor CJ, Carr JR, Rounce DR (2022). Spatiotemporal supraglacial pond and ice cliff changes in the Bhutan-Tibet border region from 2016 to 2018. Journal of Glaciology 68(267), 101-113. https://doi.org/ 10.1017/jog.2021.76

Received: 23 November 2020

Revised: 4 June 2021

Accepted: 7 June 202

First published online: 6 July 2021

Key words:

Bhutan; debris-covered glaciers; ice cliffs; remote sensing; supraglacial ponds

\section{Author for correspondence:}

Caroline Jane Taylor,

E-mail: C.Taylor11@newcastle.ac.uk (c) The Author(s), 2021. Published by Cambridge University Press. This is an Open Access article, distributed under the terms of the Creative Commons Attribution licence (http://creativecommons.org/licenses/by/4.0/) which permits unrestricted re-use, distribution, and reproduction in any medium, provided the original work is properly cited.

\section{Caroline Jane Taylor ${ }^{1} \mathbb{D}$, Joanne Rachel Carr $^{1}$ and David Robert Rounce ${ }^{2}$}

${ }^{1}$ School of Geography, Politics and Sociology, Newcastle University, Newcastle Upon Tyne NE1 7RU, UK and ${ }^{2}$ Civil and Environmental Engineering Department, Carnegie Mellon University, Pittsburgh, PA, USA

\section{Abstract}

Supraglacial ponds and ice cliffs can dramatically enhance ablation rates on debris-covered glaciers. Supraglacial ponds can also coalesce, forming moraine-dammed lakes at risk of glacial lake outburst flood (GLOF). Given Bhutanese glaciers have some of the highest ice loss rates in the Himalaya and GLOF vulnerability is high, we seek to advance our understanding of the spatial distribution and evolution of supraglacial ponds and ice cliffs. Here, we use high-resolution $(3 \mathrm{~m})$ Planet Labs satellite imagery to provide the first short-term, high-resolution dataset of supraglacial pond and ice cliff evolution for three glaciers along the Bhutan-Tibet border from 2016 to 2018 . A total of 5754 ponds and 2088 ice cliffs were identified. Large intra-annual changes were observed, with ponded area changes and drainage events coinciding with the seasonality of the Indian Summer Monsoon. On average, $\sim 19 \%$ of the total number of ponds had a coincident ice cliff. Pond spatial distribution was driven by ice-surface velocities, with higher numbers of ponds found in areas of low velocity $\left(<8 \mathrm{~m} \mathrm{a}^{-1}\right)$. Our study provides the first detailed, quantitative investigation of supraglacial ponds and ice cliffs in Bhutan, providing a framework for further monitoring in this understudied, yet important, region of the Himalaya.

\section{Introduction}

High Mountain Asia (HMA) contains $>70000 \mathrm{~km}^{2}$ of glacial ice (Barnett and others, 2005; Li and others, 2008), which is both an important water resource and major natural hazard. Glaciers in HMA are experiencing considerable mass loss that has accelerated in recent decades (Maurer and others, 2019; Shean and others, 2020) and is projected to increase in the future (Rounce and others, 2020). This has led to increasing concern over water resources, with an estimated $221 \pm 59$ million people dependent on glacial meltwater runoff during the dry season (Huss and Hock, 2018; Pritchard, 2019; Nie and others, 2021). This rapid ice loss has also led to the development and expansion of glacial lakes, where glacial lakes in Southeast Asia (representing Nepal, Northern India, Bhutan and Southwest China) have experienced a $45 \%$ increase in area in recent decades (Shugar and others, 2020). Within this region, Bhutan has some of the highest rates of mass loss (King and others, 2019; Shugar and others, 2020) and consequently the number and size of glacial lakes has increased substantially. Bhutan's population, agriculture and administrative sites are generally located along major river valleys, and as a nation is highly dependent on hydroelectric power (e.g. Dorji and others, 2016). As such Bhutan is one of the most vulnerable countries to glacier outburst floods (Carrivick and Tweed, 2016). Thus, quantifying changes in water storage associated with Himalayan glaciers is vital for enabling resource forecasting and identification of hazards in a region that is heavily reliant on, and vulnerable to, glaciers.

Glacier response to climate change across HMA is complicated by the presence of supraglacial debris (e.g. Benn and others, 2012; Kraaijenbrink and others, 2016). Thin or scattered debris enhances ablation rates compared to clean ice, whereas a thick layer reduces ablation rates (Östrem, 1959). At the glacier scale, thick debris near the terminus suppresses melt and thinner debris at higher elevations enhances it, thus creating an inverse mass-balance gradient, which reduces the driving stresses at the glacier tongue causing the glacier to stagnate and potentially develop supraglacial ponds and moraine-dammed glacial lakes (e.g. Reynolds, 2000; Bolch and others, 2011).

Supraglacial ponds and ice cliffs act as hotspots for ablation and can locally enhance ablation rates by a factor of three to 13 compared to the surrounding debris-covered ice (Buri and others, 2016a; Brun and others, 2018). Ponds and ice cliffs tend to form in similar areas of the glacier, and ponds with bordering ice cliffs generally expand more rapidly (Watson and others, 2016); however, the short-term dynamics of supraglacial ponds and ice cliffs are still poorly understood (Miles and others, 2016; Watson and others, 2016, Herreid and Pellicciotti, 2018). Thus, despite representing a small percentage of a glacier's area, their spatial and temporal variabilities are important to quantify to understand their impact on glacier ablation rates and glacier outburst flood hazard.

Here, we use Planet Labs satellite imagery ( $3 \mathrm{~m}$ resolution) from January 2016 to December 2018 to quantify the spatio-temporal variations of supraglacial ponds and ice cliffs for three debris-covered glaciers south of the Bhutan-Tibet border at seasonal scales. We first assess 
the spatial and temporal patterns of supraglacial pond characteristics (area, number and location). We then manually map glacier ice cliff characteristics (length, number and location) and investigate the relationship between ice cliffs and ponds. Finally, we assess the impact of glacier surface velocities on the spatial distribution and characteristics of supraglacial ponds and ice cliffs. Our results advance the process-based understanding of the impact of supraglacial features on glacier ablation and highlight the need for short-term studies in order to capture the full extent of dynamic surface changes.

\section{Methods}

\subsection{Study site}

Our study focuses on three debris-covered glaciers in Northern Bhutan, where observations of supraglacial ponds and ice cliffs have been sparse (Fig. 1). These three glaciers were chosen due to their differences in elevation, presence of tributaries, variations in length and area and the presence of large supraglacial ponds. Mool and others (2001) referred to these glaciers as Mangd_gr 116, Mangd_gr 117 and Cham_gr 25, i.e. numbers based on their sub-basins (Mangde $\mathrm{Chu}$ and Chhamkhar $\mathrm{Chu}$, respectively). The Randolph Glacier Inventory 6.0 (RGI Consortium, 2017) refers to these as only two glaciers (RGI60-15.02231 and RGI60-15.02637, respectively). In this study, we treated the tributary glacier of RGI60-15.02231 separately. For simplicity, we refer to them as Glacier 1 (G1), Glacier 2 (G2) and Glacier 3 (G3). G1 is the longest of the three glaciers $(9.9 \mathrm{~km})$, followed by G2 $(8.2 \mathrm{~km})$ and $\mathrm{G} 3(7.7 \mathrm{~km})$. The glaciers flow predominantly south, have high altitude accumulation areas (mean elevations above $5000 \mathrm{~m}$ a.s.l.) and extensive debris-covered tongues. The debris-covered area was manually delineated and only ponds in the debris-covered areas were included in the analysis. Mool and others (2001) previously mapped supraglacial ponds on G3 and a field visit was conducted in 1999 (Karma and Taman, 1999). G3 has a large supraglacial pond at its terminus (referred to here as G3-A), which is discussed separately, since its large area would skew results and mask any trends in the area of the other ponds. For reference, in December 2018 the total area of pond G3-A was more than double that of the area of all 63 supraglacial ponds present on G3 $\left(220135 \mathrm{~m}^{2}\right.$ comparative to $102711 \mathrm{~m}^{2}$ respectively).

\subsection{Data sources}

We used 49 images derived from level 3B tiles collected by the PlanetScope One Satellite constellation ( $3 \mathrm{~m}$ resolution) between January 2016 and December 2018 (Table S1, Fig. 2; https:// www.planet.com/). Due to data availability, we supplement these data with eight scenes derived from RapidEye Ortho-tiles ( $5 \mathrm{~m}$ resolution) from January 2016, February 2016 and January 2017. These images constituted all the clear-sky $(<5 \%$ cloud coverage over the glacier area) images over the three glaciers. To assess the seasonal pattern of pond formation and drainage, images were selected from each season according to Steiner and others (2019): winter (1 December to 28 February), pre-monsoon (1 March to 15 June), monsoon (16 June to 15 September) and post-monsoon (16 September to 30 November). Due to the limited data availability, the number of images per season, per year and per glacier vary. For winter, we have images for every month and year, so we have high confidence in the associated patterns. Coverage for post-monsoon was near-complete, missing one data point from September 2016 for all three glaciers. Pre-monsoon and monsoon were far more sporadic, which is a common problem with optical remote-sensing studies in monsoonal regions where dense cloud-cover and snow cover limits observations (Miles and others, 2017). G3 had one premonsoon season image and one monsoon season each year, whereas G1 and G2 were only imaged in 2017 and 2018. Given pre-monsoon was represented by one month on one glacier only (G3) we have excluded pre-monsoon from our analysis. We acknowledge this sporadic temporal coverage potentially causes bias issues in the monsoon season and discuss this within the text.

\subsection{Supraglacial ponds}

The normalised difference water index (NDWI) (McFeeters, 1996) uses the ratio between the near-infrared and green bands to separate areas of water and non-water, and has been successfully used to delineate supraglacial ponds in the Langtang and Everest regions of Nepal (e.g. Bolch and others, 2008; Bolch and others, 2011; Kraaijenbrink and others, 2016). We use Otsu's adaptive histogram-based method to select an optimised NDWI threshold for each scene (Otsu, 1979; Cooley and others, 2017). This method iterates through all the possible threshold values, calculates a measure of spread for the pixels on each side of the threshold and selects the threshold value where the spread of pixels in the foreground and background is at its minimum. The resulting threshold was then used to reclassify the study imagery into a binary image of ponds (1) and anything else (0) (Fig. 3). Threshold values between 0.3 and 0.4 produced the most accurate identification of supraglacial ponds, with minimal omissions. The resultant binary image was converted to polygons, with each polygon representing an individual supraglacial pond (Fig. 3c). Polygons produced via the NDWI threshold were manually adjusted where required, e.g. where ponds were frozen, partially frozen and/or had a high sediment content (Fig. 3d). Each mapped pond was given an ID, enabling ponds that drained to be matched despite the change in location due to glacier velocity.

To identify any differences in the ponds mapped on both RapidEye and Planet Labs images, we compared our NDWI classification for two images from the same date and found the area of supraglacial ponds agreed well; on average ponds mapped on RapidEye images had an area $4.8 \%$ greater than the same ponds mapped on Planet Labs images. Hence, the use of RapidEye images has minimal impact on our lake area statistics (Fig. S1). We estimate total uncertainty for the automatically identified ponds using a \pm 0.5 pixel boundary (e.g. Salerno and others, 2012; Wang and others, 2013), which estimates the average error to be $28 \%$. We checked the accuracy of this assumed \pm 0.5 pixel boundary by manually delineating a subset of 58 supraglacial ponds of different sizes. The area of all 58 manually digitised and automatically identified ponds agreed well (Fig. S2b). The average error, expressed as a percentage of total area, was $7.0 \%$. This indicates that we conservatively estimate uncertainty using the pixel boundary approach.

\subsection{Ice cliffs}

Ice cliffs were manually delineated using the same satellite imagery as for the ponds. Here, we define ice cliffs as any exposed, sloping ice, whether that be clean ice or 'dirty' ice (i.e. a thin layer of debris may cover all or part of the cliff). The top-edge of ice cliffs on each of the glacier surfaces was manually digitised in a left to right direction with the cliff facing outwards. We delineated the top-edge of the ice cliffs to determine their length and orientation but did not estimate area since this requires a highresolution digital elevation model (Watson and others, 2017a). Previous study suggests that ponds with bordering ice cliffs 


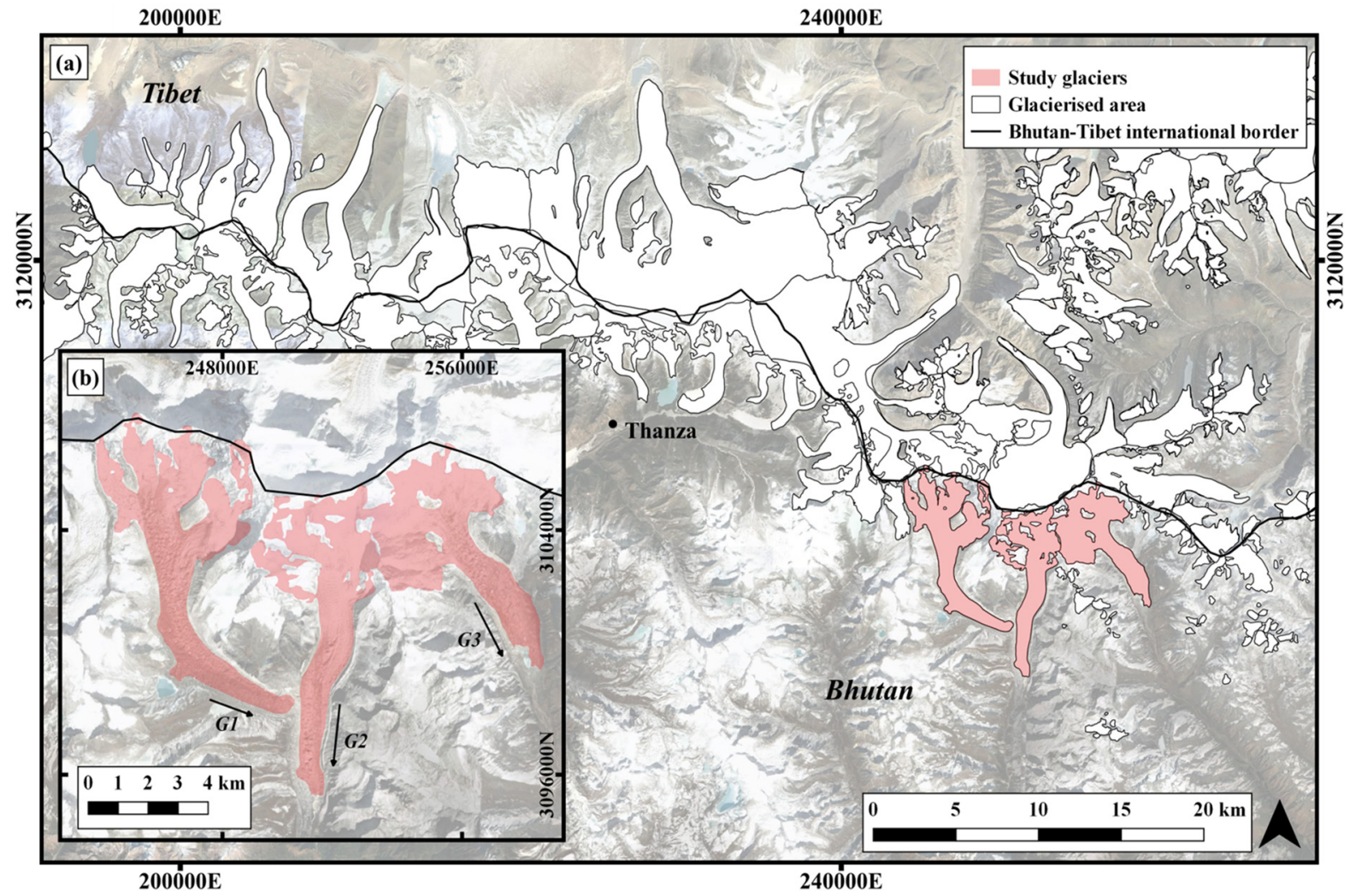

Fig. 1. (a) Glacierised area within the study region along the Bhutan-Tibet border, showing the glaciers (red). The inset (b) shows the three selected debris-covered glaciers (from left to right; G1, G2 and G3). Background: Planet Labs image from 24 January 2018.
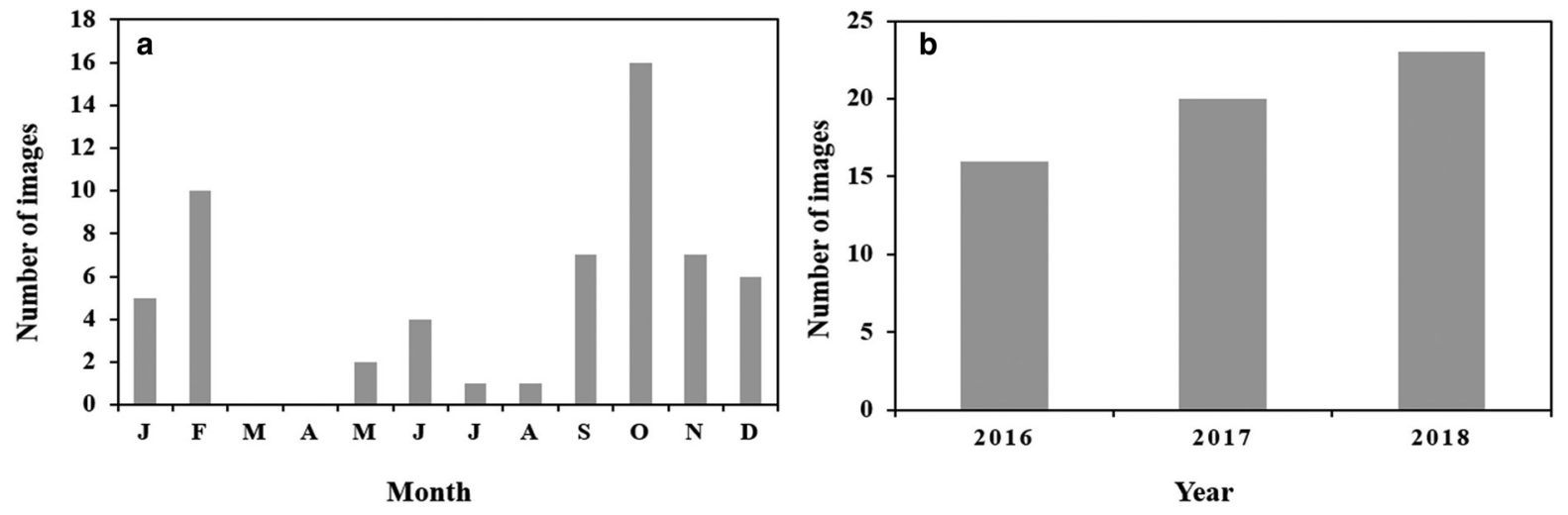

Fig. 2. Temporal distribution of scenes processed in the study, with the number of images per month: (a) and per year and (b) ( $n=56$ ).

experience higher rates of expansion (e.g. Watson and others, 2016); however, since cliffs are near vertical, it is difficult to determine whether a pond intersects with a cliff using only the top-edge of the ice cliff. Therefore, we used a $30 \mathrm{~m}$ directional buffer from the top-edge of each cliff to determine if the ice cliff was in contact with a pond (Fig. S3). Direction was assumed from the side facing or in contact with the pond itself, and any pond within this buffer was said to have an adjacent cliff. Ice cliffs can only persist where you have clean ice or ice with a very thin debris veneer. Therefore, cliffs have to be at or above the angle of repose to form. Thus, the $30 \mathrm{~m}$ buffer is derived from the average debris angle of repose of $30^{\circ}$ (e.g. Sakai and others, 1998), and using an approximated upper bound for a steeply sloping cliff face of $15 \mathrm{~m}$ (Benn and others, 2001; Thompson and others, 2016).

Uncertainty in ice cliff length is determined by the resolution of the images used for digitisation, operator misidentification of cliffs and operator digitisation of the cliffs (Watson and others, 2017a). Given that high-resolution imagery was used, and one operator undertook all the analysis, the manual digitisation is likely the largest source of error. To quantify these errors, 50 of the total 2088 cliffs were randomly selected and re-digitised (Fig. S2a). The original and repeat cliff lengths showed good agreement; lengths of repeat-digitised cliffs were on average no more than $3.0 \%$ different to that of the original cliffs. The difference between the two had a low std dev. $(4.3 \mathrm{~m})$ indicating that the manual digitising error was low.

\subsection{Controls on pond formation}

We assessed how glacier surface velocities affect supraglacial pond formation and growth. Glacier surface velocities $(120 \mathrm{~m}$ resolution) were provided by the NASA MEaSUREs ITS_LIVE project (Gardner and others, 2019), generated using the auto-RIFT 

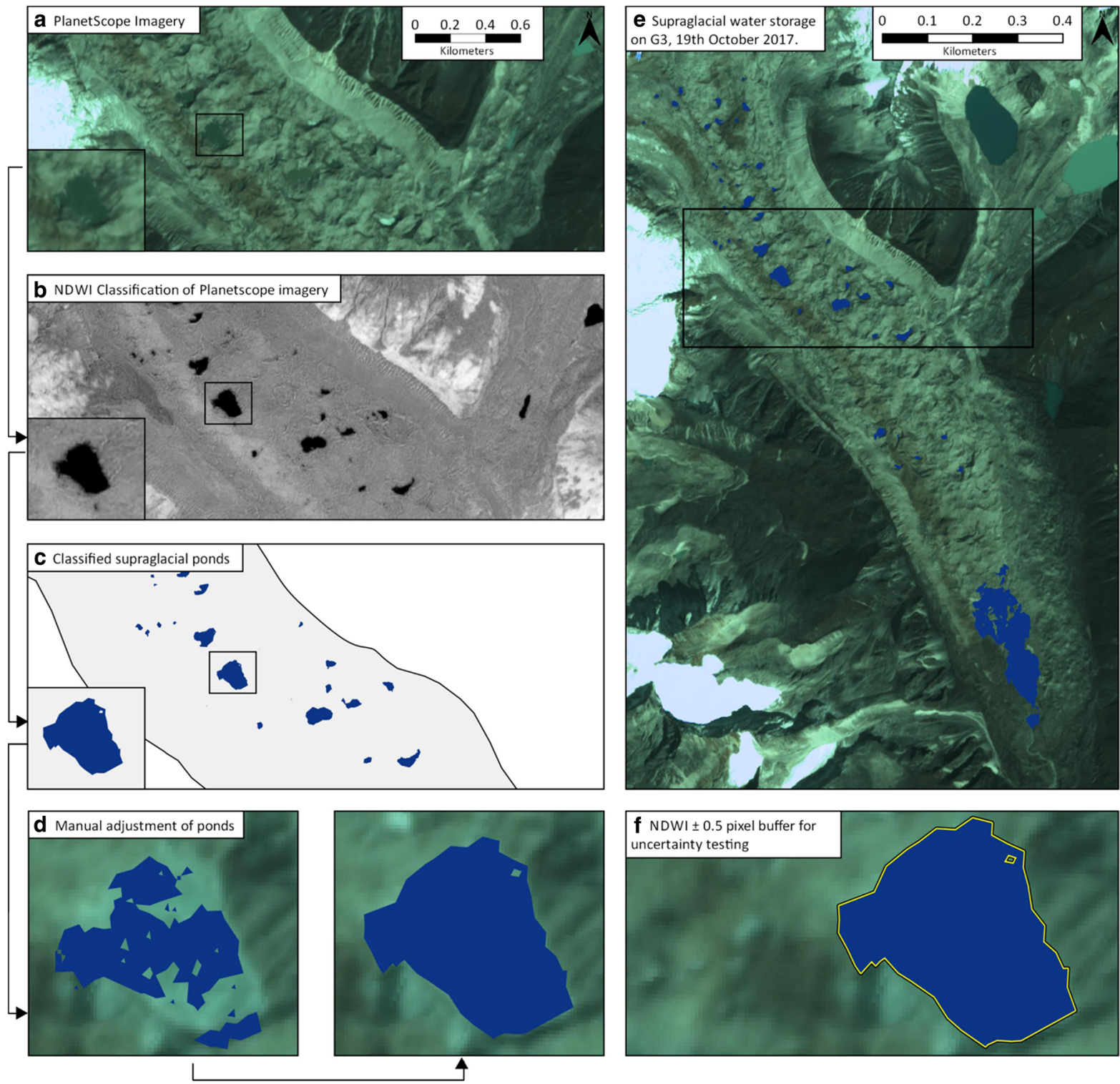

Fig. 3. Workflow of pond classification using the NDWI method on PlanetScope. (a) Original PlanetScope mosaic, (b) NDWI to delineate surface water, (c) classified supraglacial pond polygons, (d) manual adjustment of pond polygons due to floating ice/sediment content/boundary conditions, (e) final identified supraglacial ponds on G3 (19th October 2017) and (f) half pixel uncertainty assessment. Background image: Planet Labs, 19/10/2017.

feature tracking processing chain described in Gardner and others (2018). For each glacier, velocity profiles were extracted along the glacier's centreline in $500 \mathrm{~m}$ horizontal bins from the terminus up-glacier. These binned velocities were used to compare pond locations and surface velocities for the three glaciers. Considerations of debris thickness and surface slope are also included in the discussion however not analysed in detail here. Thickness estimates were provided by Rounce and others (in review) and slope determined using the HMA $8 \mathrm{~m}$ DEM (Shean, 2017).

\section{Results}

\subsection{Supraglacial pond changes}

3.1.1 Spatial and temporal pond variations between glaciers Average pond area in the study region was $1206 \mathrm{~m}^{2}$, with ponds on G3 on average the largest $\left(1645 \mathrm{~m}^{2}\right)$ and ponds on $\mathrm{G} 2$ the smallest $\left(805 \mathrm{~m}^{2}\right)$. The total ponded area for our three glaciers between January 2016 and December 2018 varied considerably spatially and seasonally (Table 1; Fig. 4). G1 had the highest average ponded area of $175855 \mathrm{~m}^{2}$, which was 3.5 times more than that of G2 $\left(49329 \mathrm{~m}^{2}\right)$ and 1.5 times more than that of G3 $\left(116969 \mathrm{~m}^{2}\right)$. Similarly, the average number of ponds on G1 (156) was 2.5 times more than those on G2 (62) and two times more than those on G3 (78). G2 consistently had the lowest ponded area and pond number. During the study period, all three glaciers demonstrated marked temporal variations in ponded area, with G3 having the largest range at almost $200000 \mathrm{~m}^{2}$. G1 had the largest range with respect to numbers of ponds (100). There was an overall decrease in the percentage ponded area on G1 and G2 between January 2016 and December 2018.

Seasonal variations on G2 and G3 showed that the ponded area was higher during the winter season (Fig. 4). Specifically, the average ponded area was 5.0 and $21.3 \%$ higher in the winter than in the monsoon season average, and 39.28 and $9.89 \%$ higher than the post-monsoon average, respectively. In contrast, the average ponded area on G1 during the monsoon season $\left(179280 \mathrm{~m}^{2}\right)$ was $3.0 \%$ higher than that in winter season $\left(174006 \mathrm{~m}^{2}\right)$ and $1.6 \%$ higher than that in post-monsoon season $\left(176340 \mathrm{~m}^{2}\right.$; Fig. 4). These spatio-temporal variations clearly show glacier to glacier 
Table 1. Supraglacial pond changes during 2016-18 for the three glaciers

\begin{tabular}{|c|c|c|c|c|c|c|c|c|c|}
\hline & Date & $\begin{array}{l}\text { Number of } \\
\text { ponds }\end{array}$ & $\begin{array}{l}\text { Ponded area } \\
\mathrm{m}^{2}\end{array}$ & $\begin{array}{c}\text { Error } \\
\left( \pm 0.5 \text { pixel } \mathrm{m}^{2}\right)\end{array}$ & $\begin{array}{l}\text { Percentage } \\
\text { ponded } \\
\text { area } \\
\%\end{array}$ & $\begin{array}{l}\text { Number of } \\
\text { ice cliffs }\end{array}$ & $\begin{array}{l}\text { Percentage of } \\
\text { ponds with ice } \\
\text { cliffs } \\
\%\end{array}$ & $\begin{array}{c}\text { Percentage of } \\
\text { ponds without } \\
\text { ice cliffs } \\
\%\end{array}$ & $\begin{array}{c}\text { Rate of pond } \\
\text { growth } \\
\% d^{-1}\end{array}$ \\
\hline \multirow[t]{19}{*}{ G1 } & $07 / 01 / 16$ & 112 & 220702 & 34.50 & 1.08 & 32 & 11.61 & 88.39 & \\
\hline & $07 / 02 / 16$ & 200 & 188370 & 37.34 & 0.92 & 60 & 18.00 & 82.00 & -0.47 \\
\hline & $23 / 10 / 16$ & 157 & 230598 & 34.01 & 1.12 & 58 & 17.83 & 82.17 & +0.08 \\
\hline & $23 / 11 / 16$ & 143 & 128455 & 42.14 & 0.63 & 37 & 11.19 & 88.81 & -1.57 \\
\hline & $22 / 12 / 16$ & 118 & 145989 & 37.25 & 0.71 & 44 & 16.10 & 83.90 & +0.47 \\
\hline & $07 / 01 / 17$ & 105 & 197610 & 25.76 & 0.96 & 42 & 27.27 & 72.73 & +2.20 \\
\hline & $16 / 02 / 17$ & 201 & 167372 & 34.46 & 0.82 & 80 & 16.59 & 83.41 & -0.38 \\
\hline & $16 / 06 / 17$ & 133 & 190125 & 33.52 & 0.93 & 66 & 27.07 & 72.93 & +0.11 \\
\hline & $05 / 09 / 17$ & 131 & 186262 & 29.33 & 0.91 & 44 & 21.37 & 78.63 & -0.03 \\
\hline & $19 / 10 / 17$ & 168 & 179564 & 40.31 & 0.88 & 63 & 19.05 & 80.95 & -0.08 \\
\hline & $10 / 11-17$ & 156 & 132289 & 44.39 & 0.65 & 45 & 12.18 & 87.82 & -1.19 \\
\hline & $04 / 12 / 17$ & 166 & 117961 & 39.07 & 0.58 & 52 & 18.67 & 81.33 & -0.45 \\
\hline & $24 / 01 / 18$ & 211 & 163855 & 38.89 & 0.80 & 47 & 14.69 & 85.31 & +0.76 \\
\hline & $02 / 02 / 18$ & 201 & 218273 & 23.72 & 1.06 & 72 & 21.17 & 78.83 & +1.44 \\
\hline & $19 / 06 / 18$ & 212 & 200338 & 38.29 & 0.98 & 98 & 14.15 & 85.85 & -0.06 \\
\hline & $08 / 09 / 18$ & 112 & 140406 & 31.11 & 0.68 & 55 & 25.00 & 75.00 & -0.93 \\
\hline & $16 / 10 / 18$ & 137 & 187025 & 29.39 & 0.91 & 61 & 24.82 & 75.18 & +0.83 \\
\hline & $25 / 11 / 18$ & 165 & 200.338 & 37.42 & 0.98 & 55 & 19.39 & 80.61 & +0.18 \\
\hline & $06 / 12 / 18$ & 135 & 145.925 & 33.98 & 0.71 & 52 & 25.40 & 74.60 & -2.25 \\
\hline \multirow[t]{19}{*}{ G2 } & $07 / 02 / 16$ & 78 & 60553 & 32.99 & 0.37 & 13 & 16.67 & 83.33 & \\
\hline & $23 / 10 / 16$ & 46 & 42724 & 33.68 & 0.26 & 33 & 15.22 & 84.78 & -0.11 \\
\hline & $23 / 11 / 16$ & 44 & 26247 & 41.13 & 0.16 & 16 & 12.20 & 87.80 & -1.29 \\
\hline & $22 / 12 / 16$ & 40 & 46866 & 28.14 & 0.28 & 20 & 12.50 & 87.50 & +2.71 \\
\hline & $07 / 01 / 17$ & 22 & 34517 & 25.36 & 0.21 & 11 & 21.95 & 78.05 & -1.64 \\
\hline & $16 / 02 / 17$ & 42 & 31494 & 34.65 & 0.19 & 33 & 23.81 & 76.19 & -0.22 \\
\hline & $16 / 06 / 17$ & 38 & 32975 & 35.79 & 0.20 & 34 & 28.95 & 71.05 & +0.04 \\
\hline & 05/09/17 & 43 & 32116 & 36.50 & 0.19 & & 16.28 & 83.72 & -0.03 \\
\hline & $19 / 10 / 17$ & 74 & 37430 & 49.53 & 0.23 & 37 & 13.51 & 86.49 & +0.38 \\
\hline & $10 / 11-17$ & 52 & 22892 & 48.64 & 0.14 & 15 & 9.62 & 90.38 & -1.77 \\
\hline & $04 / 12 / 17$ & 57 & 55723 & 28.71 & 0.34 & 11 & 10.53 & 89.47 & +5.98 \\
\hline & $24 / 01 / 18$ & 112 & 59762 & 37.63 & 0.36 & 18 & 6.25 & 93.75 & +0.14 \\
\hline & $02 / 02 / 18$ & 104 & 136561 & 22.16 & 0.83 & 41 & 17.31 & 82.69 & +5.59 \\
\hline & $19 / 06 / 18$ & 116 & 122108 & 32.76 & 0.74 & 36 & 9.48 & 90.52 & -0.08 \\
\hline & $06 / 07 / 18$ & 75 & 60631 & 34.99 & 0.37 & & 22.67 & 77.33 & -2.96 \\
\hline & $08 / 09 / 18$ & 51 & 23873 & 43.26 & 0.14 & 9 & 7.84 & 92.16 & -1.89 \\
\hline & $16 / 10 / 18$ & 52 & 23542 & 39.66 & 0.14 & 32 & 11.54 & 88.46 & -0.03 \\
\hline & $25 / 11 / 18$ & 72 & 55061 & 35.53 & 0.33 & 16 & 16.67 & 83.33 & +3.43 \\
\hline & $06 / 12 / 18$ & 56 & 32196 & 39.89 & 0.20 & 23 & 10.71 & 89.29 & -3.46 \\
\hline \multirow[t]{21}{*}{ G3 } & $07 / 01 / 16$ & 49 & 116702 (122 007) & 26.58 & $0.77(\mathbf{0 . 8 0})$ & 16 & 24.49 & 75.51 & \\
\hline & $07 / 02 / 16$ & 122 & 151518 (156 111) & 41.29 & $1.00(1.03)$ & 34 & 21.31 & 78.69 & +0.96 \\
\hline & $27 / 08 / 16$ & 53 & 85,939 (256 493) & 36.70 & $0.57(\mathbf{1 . 6 9 )}$ & 14 & 18.87 & 81.13 & -0.19 \\
\hline & $23 / 10 / 16$ & 90 & 132651 (229 500) & 36.49 & $0.87(\mathbf{1 . 5 1 )}$ & 46 & 25.56 & 74.44 & +1.55 \\
\hline & $23 / 11 / 16$ & 64 & $80534(\mathbf{2 1 0} 480)$ & 34.66 & $0.53(\mathbf{1 . 3 8})$ & 21 & 17.19 & 82.81 & -1.31 \\
\hline & $22 / 12 / 16$ & 69 & 74275 (193 527) & 36.68 & $0.49(1.27)$ & 29 & 17.39 & 84.06 & -0.27 \\
\hline & $07 / 01 / 17$ & 43 & 114211 (235 309) & 23.98 & 0.75 (1.55) & 19 & 24.49 & 75.51 & +3.36 \\
\hline & $16 / 02 / 17$ & 139 & 122415 (191 966) & 35.50 & $0.81(1.26)$ & 34 & 14.39 & 85.61 & +0.18 \\
\hline & $16 / 06 / 17$ & 60 & 102643 (250 962) & 35.01 & $0.67(1.65)$ & 37 & 21.67 & 78.33 & -0.13 \\
\hline & $17 / 07 / 17$ & 66 & 100108 (250 962) & 34.49 & $0.66(1.65)$ & 29 & 30.30 & 69.70 & -0.08 \\
\hline & $05 / 09 / 17$ & 61 & 88369 (209 227) & 35.18 & $0.58(1.38)$ & 31 & 21.31 & 78.69 & -0.23 \\
\hline & $19 / 10 / 17$ & 67 & 111297 (248 455) & 40.06 & $0.73(1.63)$ & 40 & 29.85 & 70.15 & +0.59 \\
\hline & $10 / 11-17$ & 67 & 77553 (213 483) & 38.86 & $0.51(1.40)$ & 29 & 21.05 & 78.95 & -1.39 \\
\hline & $04 / 12 / 17$ & 65 & 109236 (169 389) & 30.64 & 0.72 (1.14) & 30 & 23.08 & 61.54 & +1.70 \\
\hline & $24 / 01 / 18$ & 129 & 100908 (203 942) & 44.11 & $0.66(1.34)$ & 29 & 16.28 & 91.47 & -0.13 \\
\hline & $02 / 02 / 18$ & 134 & $263534(240900)$ & 20.69 & 1.73 (1.58) & 38 & 17.16 & 82.84 & +7.01 \\
\hline & $19 / 06 / 18$ & 108 & 156605 (268 686) & 35.41 & 1.03 (1.77) & 30 & 19.44 & 80.56 & -0.30 \\
\hline & $08 / 09 / 18$ & 48 & 72879 (225 316) & 42.20 & $0.48(1.48)$ & 28 & 25.00 & 75.00 & -1.67 \\
\hline & $16 / 10 / 18$ & 49 & 159959 (292 094) & 30.15 & 1.05 (1.92) & 31 & 28.57 & 71.43 & +2.99 \\
\hline & $25 / 11 / 18$ & 91 & 132256 (245 863) & 35.55 & $0.87(1.62)$ & 34 & 23.08 & 76.92 & -0.45 \\
\hline & $06 / 12 / 18$ & 63 & 102711 (220 135) & 32.78 & 0.68 (1.45) & 28 & 20.00 & 80.00 & -1.86 \\
\hline
\end{tabular}

Dates are coloured by season; blue (winter), red (monsoon) and pink (post-monsoon). Values in brackets for Glacier 3 represent the area of pond G3-A.

variation in ponded area, number and seasonality, despite their close proximity.

The percentage ponded area (defined as percentage of the total debris-covered glacierised area occupied by supraglacial ponds) also varied over the study period for all three glaciers (Table 1). G2 had the lowest percentage ponded area, ranging from a minimum of $0.3 \%$ in November 2017 to a maximum of $1.7 \%$ in February 2018. The largest range in percentage ponded area was found on G3, which varied from 1.0\% in September 2018 to $3.5 \%$ in February 2018. The highest percentage ponded area was recorded on G2 and G3 in February 2018, which experienced an increase between January 2018 and February 2018 of 0.7 to $1.7 \%$ on G2 and 1.4 to $3.5 \%$ on G3. The rate of pond growth on each glacier changed over the study period; however, no significant overall trends can be observed due to the sporadic temporal coverage (Fig. S4 and Table 1). 

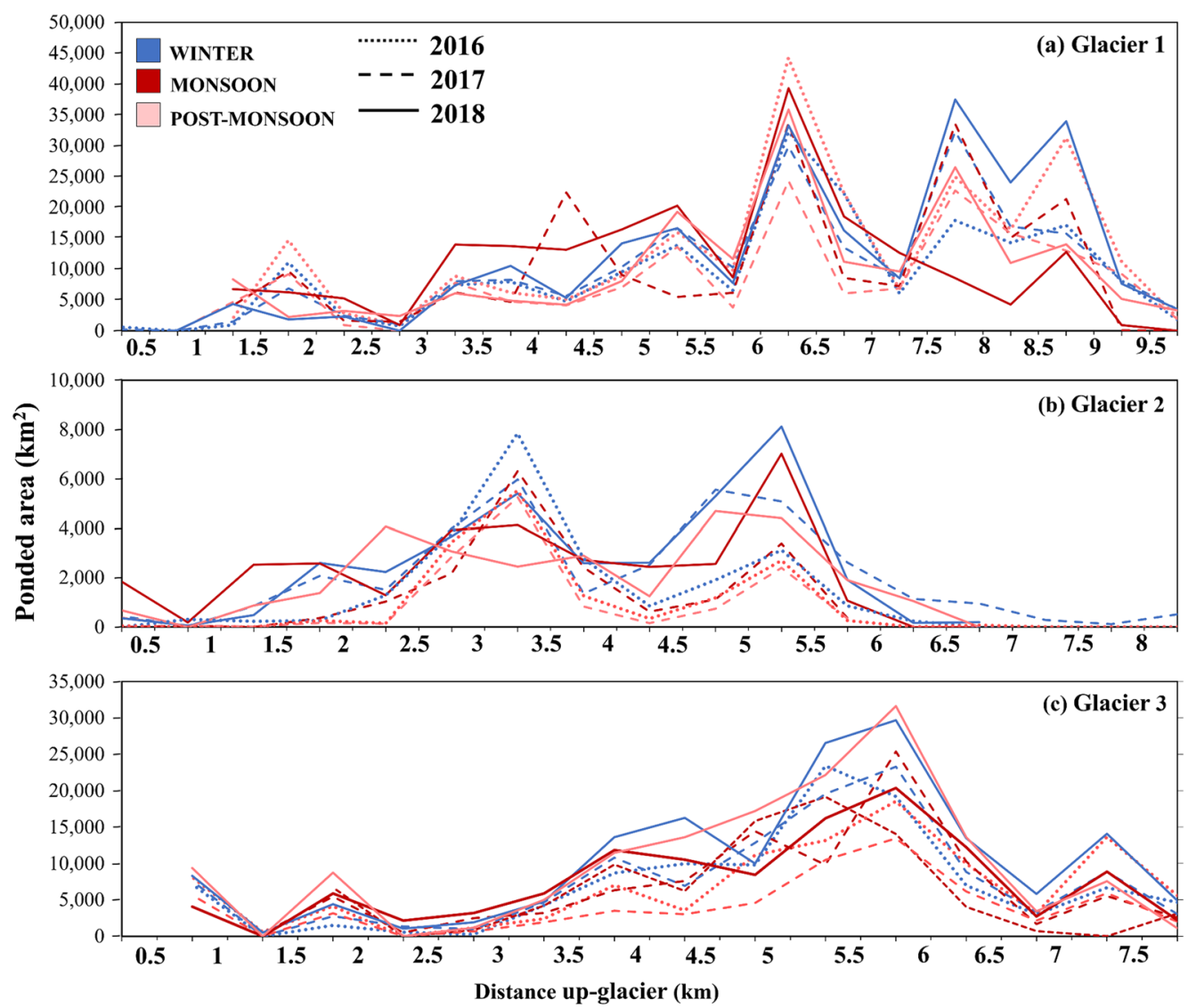

Fig. 4. Spatial and temporal changes during 2016-18 for the three glaciers showing ponded area change with distance up-glacier from the terminus for glaciers (a) G1, (b) G2 and (c) G3. Profiles are derived from ponded area per $500 \mathrm{~m}$ distance bins. Note that ponded area tends to increase with distance up-glacier, but with high degree of variation between seasons.

\subsubsection{Spatial patterns of ponding across glaciers}

Generally, the spatial patterns of supraglacial ponding remained similar throughout the study period for all three glaciers, subject to seasonal variations (Fig. 4). On G2 and G3, pond number and ponded area were generally higher of 4 and $6 \mathrm{~km}$ up-glacier, with fewer ponds found near the glacier termini or at higher elevations (Fig. 7). However, on G3, during the winter, ponded area increased further up-glacier (above $6 \mathrm{~km}$ ), while during the monsoon season ponding increased on the lower glacier (below $4 \mathrm{~km}$ from the terminus). A similar trend was observed on G2, with a shift from mid-glacier ponding during the winter season to lowerglacier ponding during the monsoon season (Fig. 4b). The spatial pattern of ponding on G1 differs from the other glaciers, with two distinctive zones of higher ponded area and number (zone 1: km up-glacier; zone 2: above $7.5 \mathrm{~km}$ up-glacier) separated by a zone with lower ponded area and number of ponds (note: while not physically separated we have distinguished the two 'zones' based on the different observed spatial distribution of surface ponds as separating them aids interpretation). This divide is evident throughout the study period (2016-18) with notably fewer ponds between 7.0 and $7.5 \mathrm{~km}$ up-glacier (Fig. 4a). Similar to G2 and G3, ponded area and number increased on the lower glacier on G1 during the monsoon season. Persistence and coalescence of ponds through the study period means G1 is developing a chain of connected ponds on its eastern margins at $0.5-2.5 \mathrm{~km}$ up-glacier.

\subsubsection{Pond drainage}

Our data provide evidence for both pond drainage and persistence. Here, we define drainage as the disappearance and reappearance of a pond in the same location between imaging periods, i.e. one complete drainage and refill. Most ponds persisted between seasons and years $(98.2 \%$ of the total ponds detected during the study period persisted), while a total of $103(1.8 \%)$ ponds drained and refilled (Fig. 5). The most drainage and refill events occurred on G1 (34) and the least on G2 (14). Of these 103 drainage and refill events, 52 occurred once, 21 twice and only three ponds underwent three complete drainage and refill cycles during the study period (two on G1 and one on G3). We find no limit to the size of ponds that drain. Although these drain-and-fill events occurred across each glacier, they were generally located on the middle to upper portion of G1 and G3 (i.e. above 5 and $4 \mathrm{~km}$ up-glacier, respectively). Only four ponds drained in the first 5 $\mathrm{km}$ on G1, whereas all 28 drainage events on G3 occurred above $3.6 \mathrm{~km}$ up-glacier. In comparison, all 14 drainage events on G2 occurred in the middle or lower portion of the glacier, below $5.6 \mathrm{~km}$ up-glacier. On average, the most frequent season for ponds to drain was the monsoon, with 51 recorded events (equivalent of eight per month during the monsoon months) with the other two seasons experiencing the same frequency (three per month) (Fig. 5). Given the sporadic data coverage during monsoonal periods, there is uncertainty here.

\subsubsection{Pond G3-A}

Pond G3-A, a large supraglacial pond on the lower terminus of G3 was assessed separately from the other supraglacial ponds due to its large size. G3-A underwent a net gain of $98120 \mathrm{~m}^{2}$ $\left(87.6 \%\right.$ increase) over the study period, varying $122010 \mathrm{~m}^{2}$ in January 2016 to $220130 \mathrm{~m}^{2}$ in December 2018 (Table 1). Ponded area also varied seasonally with the area generally smaller in the monsoon and post-monsoon and larger in the winter. No drainage events were observed for G3-A during the study period. 

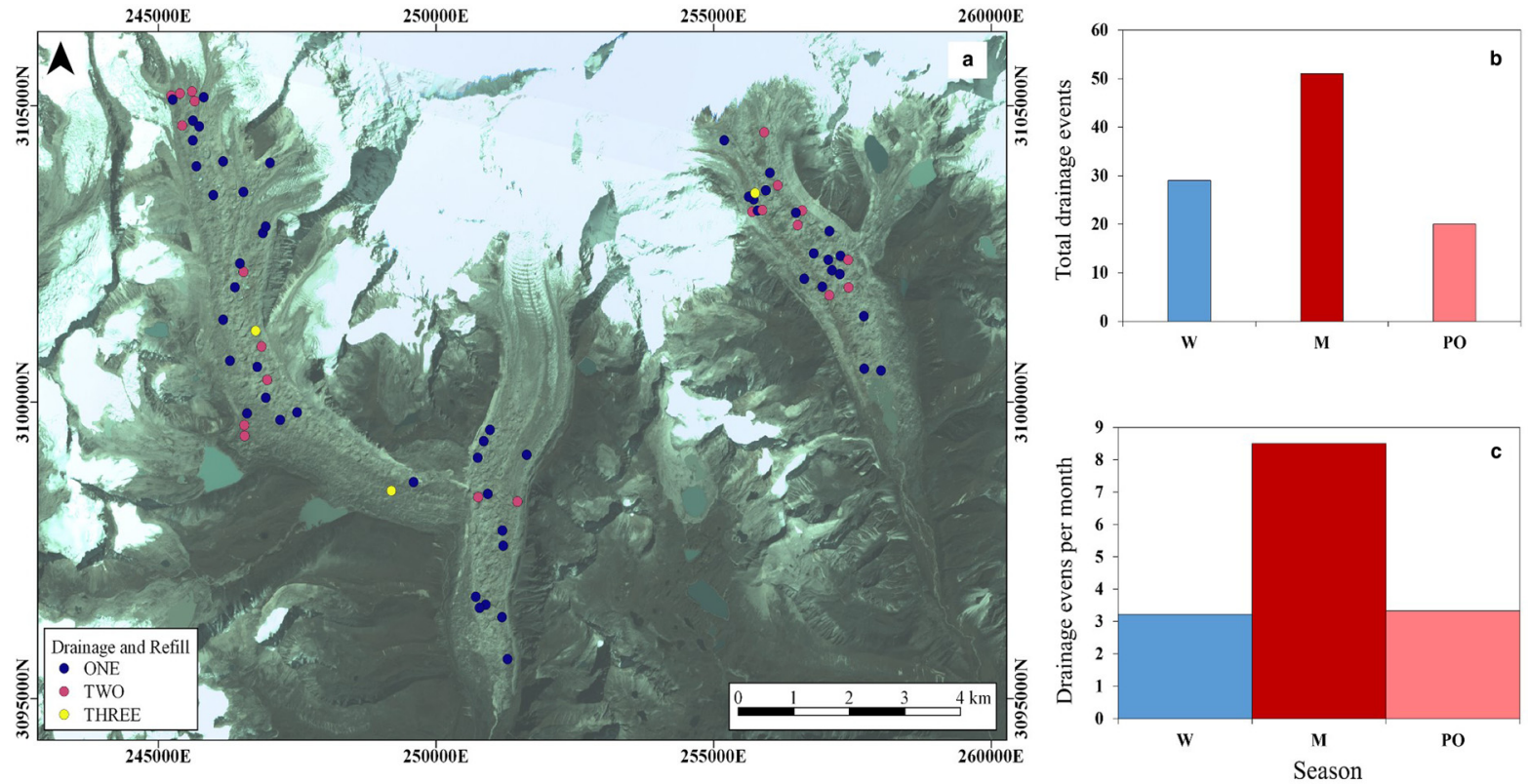

Fig. 5. (a) Location of ponds experiencing drainage and refill on the three glaciers during 2016-18. Ponds were found to drain once (blue), twice (pink) or three times (yellow). Note drainage generally occurs mid-to-high glacier on all three glaciers. (b) and (c) Total number and number per month of drainage and refill events according to seasonal distribution. The monsoon season is the only period in which we see a marked increase in drainage frequency over the study period as a whole, however the lower number of observations during this period means there is uncertainty in this finding. Background image: Planet Labs, $19 / 10 / 2017$.

\subsection{Ice cliff changes}

3.2.1 Spatial and temporal ice cliff variations between glaciers The number and spatial distribution of ice cliffs varied markedly between seasons, years and glaciers (Fig. 6). The highest number of ice cliffs were found on G1, ranging from 32 in January 2016 to 98 cliffs in June 2018. The lowest number were found on G2, ranging from nine in September 2018 to 41 in February 2018 (Fig. 6; Table 1). Most ice cliffs were located between the middle of the glacier and the terminus on all three glaciers. However, a large cluster of ice cliffs occurred at higher elevations on G1. The number of ice cliffs on G3 was the most consistent during the study period, with a std dev. of 7.5 (compared to 15.7 and 10.8 for G1 and G2 respectively; Table 1). For all three glaciers, ice cliffs generally persisted from year to year, with increases in number resulting from the formation of new cliffs, and decreases in number the result of the joining, of existing ice cliffs, rather than decay.

The average number of ice cliffs per glacier showed only a slight temporal pattern, with the average being higher during the monsoon season than in the post-monsoon and winter season on both G1 and G2. G1 averaged 66 during the monsoon and 53 during both post-monsoon and winter, whereas G2 averaged 26 in the monsoon and 25 and 23 post-monsoon and winter, respectively (Fig. 6; Table 1). In contrast, on G3, there were more cliffs on average post-monsoon (36 cliffs) than during winter and monsoon (28 cliffs each; Fig. 6). Note this difference could be due to temporal bias in observation periods, rather than an indication of seasonality. The orientation of ice cliffs was not analysed in detail for this study and thus has not been included. However, throughout all seasons cliffs generally favoured a north or northwest direction. The frequency of south, southeast and east facing cliffs was few to none, but increased marginally during monsoon season.

\subsubsection{Pond-cliff coincidence}

There were far more supraglacial ponds without a corresponding ice cliff than with. On average, only $19.0 \%$ of supraglacial ponds had a coincident cliff during the study period. The highest
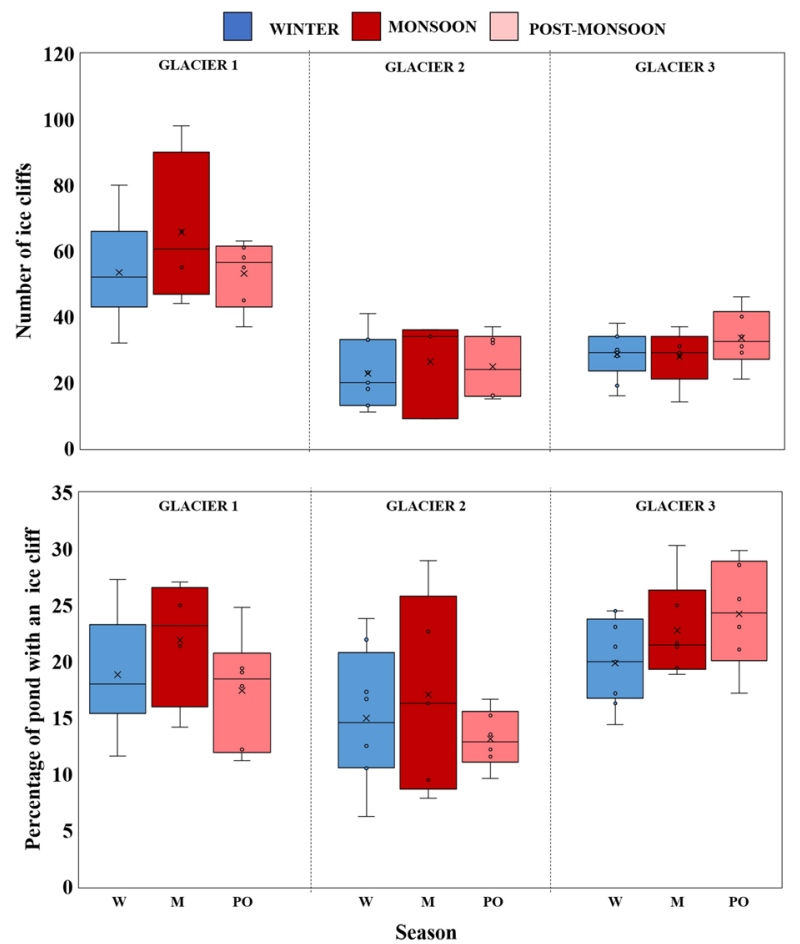

Fig. 6. (Top) Variation in the number of ice cliffs and (bottom) percentage of ponds with an ice cliff found on all three glaciers during 2016-18 for winter (blue), (red) and post-monsoon (pink). Note the box ranges highlights the lack of significant differences between seasons.

pond-cliff coincidence was found on G3, ranging from a minimum of $14.0 \%$ in February 2017 to a maximum of $29.0 \%$ in October 2017, and the lowest on G2, averaging $15.0 \%$ over the period January 2016 to December 2018. During the study period, the percentage of ice cliffs associated with a supraglacial pond increased on $\mathrm{G} 1$ by $+14.0 \%$ and decreased on $\mathrm{G} 2$ by $6.0 \%$ and on G3 by $4.0 \%$ (Table 1 ). Seasonal changes in percentage of ponds with an adjacent ice cliff varied by $<3.0 \%$, suggesting limited influence here. 


\subsection{Glacier surface velocities}

Glacier surface velocity on all three glaciers generally decreased towards the terminus (Fig. 7). Velocities were substantially higher on G1 in 2018, compared to previous years, and slightly higher at certain locations along the profiles of G2 and G3. With one exception, all drainage and refill events on G1 and G2 occurred in locations where glacier surface velocities were above $8.0 \mathrm{~m} \mathrm{a}^{-1}$. In contrast, $14(60.0 \%)$ of the drainage events on G3 occurred in areas with surface velocities between 4.0 and $8.0 \mathrm{~m} \mathrm{a}^{-1}$ and three events were in areas flowing at $<4.0 \mathrm{~m} \mathrm{a}^{-1}$. There was no apparent difference in ice velocities for ponds that drained once versus twice, but ponds that experienced three complete drainage and refill cycles were all located in areas of where glacier surface velocities were $>10.0 \mathrm{~m} \mathrm{a}^{-1}$.

\section{Discussion}

\subsection{Seasonal variation in supraglacial pond development}

\subsubsection{Temporal variation}

Over the study period, ponded area varied between months and years, as well as in location across the glacier surface, with ponded area on G1 behaving differently than ponded area on G2 and G3 (Fig. 4). Specifically, ponded area on G1 increased during the summer months, whereas it increased in winter on G2 and G3. This is unexpected, given their proximity and therefore similar climate forcing. We attribute ponded area expansion on G1 during summer to a combination of precipitation inputs from the Indian Summer Monsoon and increased meltwater generation during the summer ablation season (e.g. Irvine-Fynn and others, 2017; Miles and others, 2017). Similar summer expansion has observed in previous studies, on the Langtang Glacier, Nepal (Miles and others, 2016), in the Tien Shan (Narama and others, 2017) and in the Khumbu region, Nepal (Watson and others, 2017b). Most of the observed drainage events occurred on G1 (45.0\%) and were during the summer season (Fig. 5). We suggest this is due to an increase in available meltwater and/or rainfall, causing ponds to form on the glacier surface. These ponds then represent areas of high hydraulic potential that can more readily exploit englacial conduits to areas of lower hydraulic potential and drain into the glacier (Benn and others, 2017; Miles and others, 2017). Upon drainage, thermal energy stored within the pond water is transferred to the glacier interior and can thus enhance mass loss due to englacial ablation (e.g. Sakai and others, 2000; Miles and others, 2016; Watson and others, 2017b).

Pond area at G2 and G3 increased during the winter months (Fig. 4), which is unusual given the enhanced precipitation, pond ablation, meltwater generation and increased pond connectivity with the englacial drainage system that is usually observed during the summer months on eastern Himalayan glaciers (e.g. Sakai and others, 2000; Wang and others, 2012; Miles and others, 2016; Watson and others, 2016, 2017b). Additionally, precipitation is usually limited in winter and temperatures remain low (Mool and others, 2001; Hoy and others, 2016). Both G2 and G3 have braided networks of streams on the glacier surface during the monsoon season (Figs $8 \mathrm{c}$, e) that are no longer active by the following winter (Figs 8d, f). Compared to the terminus of G1, the surface hydrology connectivity is much less established during the summer (Fig. 8a). Therefore, we suggest the established outlet channels on G2 and G3 may be efficient in removing the excess seasonal meltwater from the surface during the summer. As meltwater supply reduces and ponds begin to freeze over during winter, the outlet channels become less efficient, leading to higher ponded area during the winter months compared to the summer period. In comparison, the poorly connected supraglacial hydrological system on the terminus of G1 may be promoting surface storage. The steeper profiles and generally higher velocities of G2 and G3 compared to G1 would facilitate this effective surface transport. Our findings therefore suggest that the efficiency of the supraglacial hydrological system at all three glaciers evolves between summer and winter, but in different ways. Under a warming climate, we might expect efficient surface drainage to persist at G2 and G3 and thus ponded areas to remain small, whereas on G1, we might expect ponded area to increase with warming. It is worth noting that recent studies have revealed that thermal energy is stored within ponds overwinter, trapped in by an insulating layer of snow-covered ice (e.g. Watson and others, 2018). Thus, further analysis of pond thermal regime would be needed to determine drivers. Additionally, the lack of pre-monsoon and sporadic monsoon data may be masking some changes during the summer months.

\subsubsection{Spatial variation between glaciers}

On our glaciers, ponds clustered in the mid-ablation zone (Fig. 4), which we attribute to the impact of debris cover on glacier dynamics. Debris cover is generally thinner $(<0.25 \mathrm{~m})$ further up-glacier on all three glaciers (Fig. S5), and therefore the underlying ice experiences more melt compared to clean-ice at higher elevations or ice insulated by thicker debris close to the terminus or glacier margins As such, the mid-ablation zone generally experiences the highest melt rates (Watson and others, 2017b), which can reduce glacier surface gradients, promote glacier stagnation (e.g. Quincey and others, 2007; Miles and others, 2017; Steiner and others, 2019) and initiate ponding. In areas where debris cover is thicker ( $>0.5$; Fig. S5), ponding is less frequent. This is further supported by our velocity data, which show that the mid-ablation zone glacier velocities on G1 and G2 were below $10.0 \mathrm{~m} \mathrm{a}^{-1}$ and below $15.0 \mathrm{~m} \mathrm{a}^{-1}$ on $\mathrm{G} 3$ suggesting a reduction in glacier flow. Although the local surface slope is generally below $20^{\circ}$ in this mid-ablation zone, there is substantial variation observed across all three glacier surfaces (Fig. S6). As such, the role of surface slope in supraglacial pond and ice cliff formation here remains unclear.

The number of ponds and ponded area were consistently higher on G1 than on the other two glaciers (Table 1). This may be due to G1's lower surface velocities (Fig. 7), where between 2016 and 2018 average surface velocities remained below $10.0 \mathrm{~m} \mathrm{a}^{-1}$ across G1's tongue; compared to G2 and G3, where velocity did not fall below $10.0 \mathrm{~m} \mathrm{a}^{-1}$ until the mid-ablation area (5.6 km up-glacier on G2, and $6.2 \mathrm{~km}$ up-glacier on G3). Ponds usually begin to form where velocities are $<10.0 \mathrm{~m} \mathrm{a}^{-1}$ (e.g. Quincey and others, 2007; Miles and others, 2017), meaning that the area in which ponds are able to form on G1 is greater, leading to the overall higher number of ponds and ponded area. However, G2 and G3 have low ice-surface velocities within $~ 3.0$ and $5.0 \mathrm{~km}$ of their termini, respectively (Fig. 7), which may help to explain why we see higher winter ponded areas on G2 and G3, i.e. low glacier velocities may produce an inefficient englacial drainage system, which would inhibit drainage and promote supraglacial ponding (e.g. Jordan and Stark, 2001; Benn and others, 2012, 2017). Future research looking at this relationship with higher resolution velocity data would be useful here. If ponds persist through seasons rather than draining and refilling, surface melting may increase, as ponds will absorb atmospheric energy for longer (Mertes and others, 2016; Miles and others, 2017). The transition from supraglacial ponds into proglacial lakes has been observed since the 1950s in the Lunana region of Bhutan, where three of the country's largest proglacial lakes are located (Luggye Tsho, Thorthormi Tsho and Raphstreng Tsho). Should the supraglacial ponds found in this study begin to coalesce, as has been observed elsewhere (e.g. Richardson and Reynolds, 2000; Quincey and others, 2007; Thompson and 


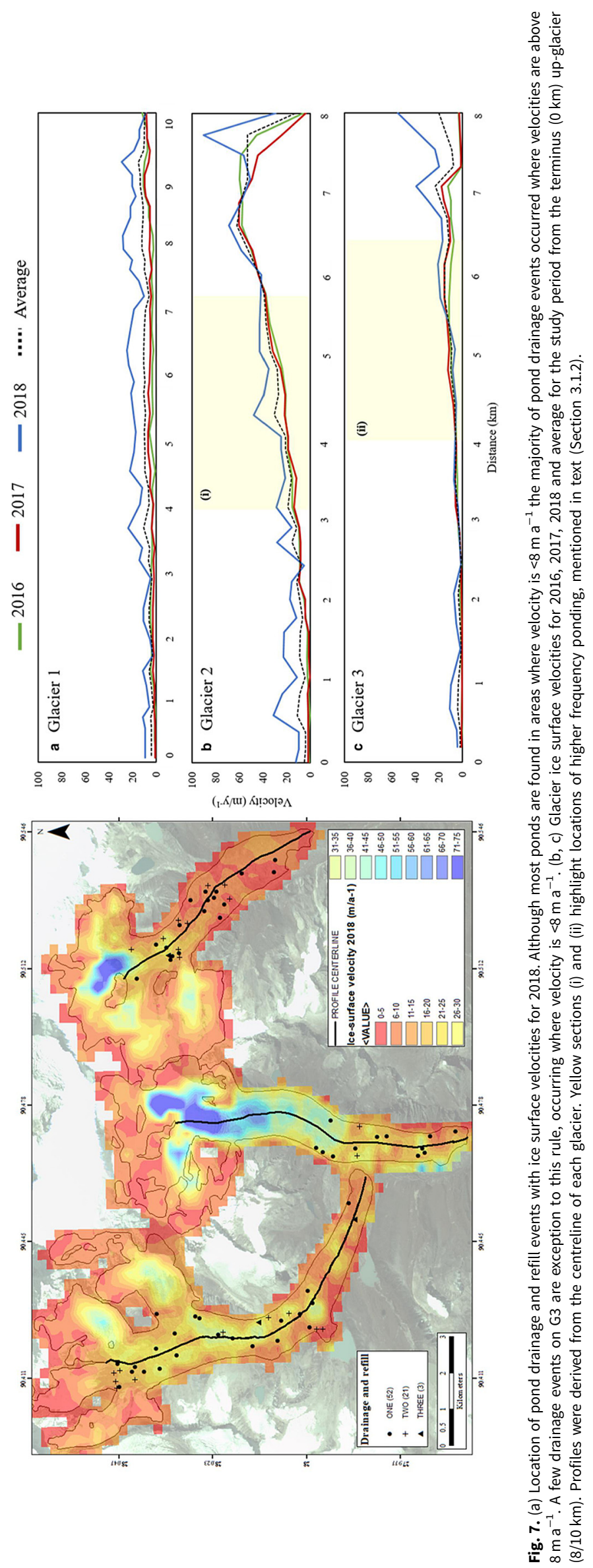




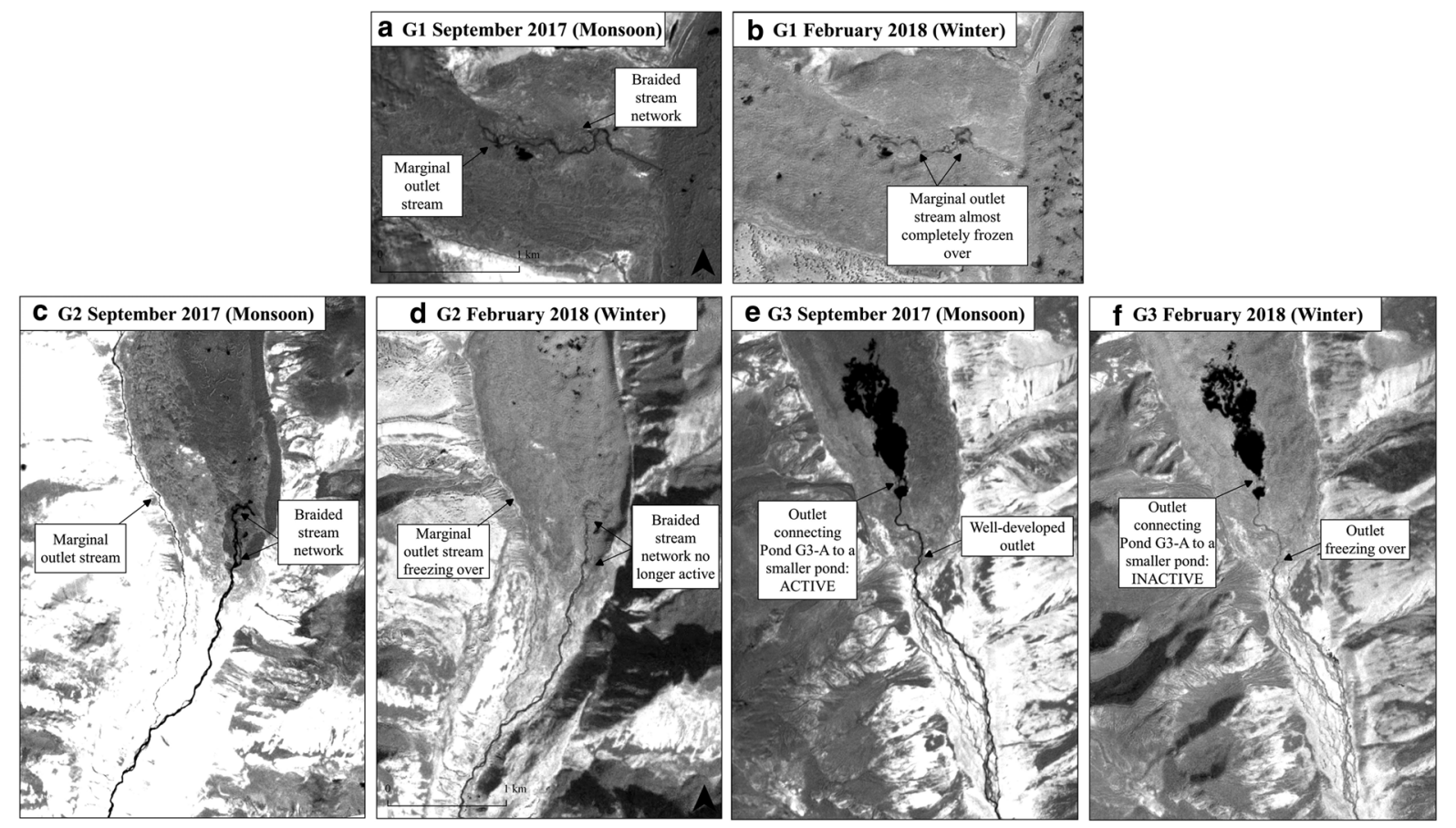

Fig. 8. Outlet stream networks on the glacier termini: (a) G1 monsoon, (b) G1 winter, (c) G2 monsoon, (d) G2 winter, (e) G3 monsoon and (f) G3 winter. Note the outlet streams are more developed during the monsoon season than the winter season. Background images are binary PlanetScope images after application of NDWI; monsoon; 05/09/17 and winter; 02/02/18.

others, 2012; Mertes and others, 2016; Watson and others, 2016) the risk of proglacial lake development at the terminus of these glaciers, and thus potential for glacial lake outburst floods will increase.

\subsubsection{Spatial variation on individual glaciers}

We observed a shift in the spatial pattern of ponding from the mid-ablation zone to lower altitudes during the monsoon season, whereas ponded area increased at higher altitudes during the winter season (Fig. 4). This spatial shift down-glacier contrasts with the Everest region of Nepal, where the location of ponds shifted up-glacier during the summer months, while pond frequency in the lower ablation zone remained low (Watson and others, 2016). Watson and others (2016) suggest this shift was due to the presence of well-connected surface hydrological systems that allow meltwater to be efficiently conveyed to the outlet during the summer months. The most pronounced spatial shift in our study was on G1, which supports our suggestion that G1 has less connected supraglacial hydrological systems in its lower ablation area. Hence, seasonal meltwater is not efficiently transported to the outlet and instead collects in topographic inversions, resulting in higher frequency ponding in the lower-ablation area.

The spatial pattern of ponds on G1 is similar overall to the other two glaciers, but also had a zone of lower ponded area/number of ponds $7.0-7.5 \mathrm{~km}$ up-glacier (Fig. 4). There are no notable changes in glacier-surface velocity at this point (Fig. 7), there is no real change in the colour or composition of the surface debris cover (Fig. 1), nor debris thickness (Fig. S5). We therefore suggest this area of limited ponding may be due to the surrounding topography. Here, a smaller source tributary from the northeast joins the trunk from the north, and the surrounding topography becomes steeper (Fig. S7). This may alter the amount of shortwave radiation reaching the glacier surface due to increased shadowing (e.g. Steiner and others, 2015), thereby reducing ablation, and thus ponding. Below this area, where the topography is less steep, shadowing is reduced and thus higher rates of ablation are experienced as more shortwave radiation is directly transmitted to the glacier surface, and for longer. Studies have suggested that surrounding topography can also expose glacial ice to more longwave- and reflected shortwave-radiation (e.g. Steiner and others, 2015). Thus, it is possible that other factors are inhibiting pond formation in this area, such as a change in wind direction (altering waterline advection and therefore impacting marginal melt) or the presence of efficient drainage networks, which warrant further investigation.

\subsubsection{Pond drainage}

Glaciers in Bhutan are summer accumulation type glaciers, i.e. they receive precipitation inputs during the ablation season, which corresponds with the middle of the Indian Summer Monsoon (Bookhagen and Burbank, 2010; Wagnon and others, 2013). Thus, glaciers are both gaining and losing mass simultaneously, which leads to increased meltwater generation that can either be retained in ponds or drained via supraglacial meltwater channels and/or englacial conduits. On all three glaciers, the most drainage events (51 events) occurred during the monsoon season, with an average of eight events per month during the monsoon season compared to just three per month in the remaining seasons (Fig. 5). This coincides with when increased meltwater supply opens conduits, thereby making englacial drainage more efficient (Miles and others, 2016; Irvine-Fynn and others, 2017). Due to the limited data coverage during the monsoon season, and data gap from the pre-monsoon season we cannot determine if this difference is significant. More confidence can be placed on trends seen for post-monsoon and winter periods given the near-continuous data coverage during these periods.

G1 experienced more drainage events (34) than the other two glaciers (14 on G2 and 28 on G3) (Fig. 5), but the percentage of the number of ponds that drained was higher on G2 $(23.0 \%)$ and G3 (35.0\%) than on G1 (22.0\%). Supraglacial ponds that repeatedly drain convey energy to the glacier interior, which can enhance englacial melt rates and lead to conduit roof collapse and the nucleation of further supraglacial ponds in the resulting depressions (e.g. Sakai and others, 2000; Mertes and others, 
2016; Miles and others, 2016, 2017). Thus, these drainage events may be contributing to the overall higher ponded area and number of ponds seen on G1 as there are more topographic depressions for meltwater to accumulate. G2 and G3 experienced fewer drainage events than G1, supporting the idea that both glaciers have established supraglacial hydrological systems that deliver ponded water to the proglacial environment, rather than draining via englacial conduits. In contrast, the inefficient surface hydrological system on G1 (Fig. 8) may allow ponded area to increase, which increases the chances of englacial drainage, as ponds expand via horizontal and lateral melting (e.g. Benn and others, 2001).

On debris-covered glaciers, widespread downwasting of glacier surfaces results in reduced driving stresses and thus reduced glacier surface velocities (Benn and others, 2012). In locations where velocities are low, inefficient englacial drainage pathways exist, promoting the development of supraglacial ponds (Jordan and Stark, 2001; Benn and others, 2012, 2017); hence, glacier surface velocities drive patterns of pond drainage or persistence and determine pond size (e.g. Miles and others, 2017). We therefore expect a higher number of ponds and larger ponded area where surface velocities are lower (e.g. Thompson and others, 2016; Miles and others, 2017; Watson and others, 2017b). Our results support this, with a higher ponded area and number of ponds found in areas where surface velocities $<10.0 \mathrm{~m} \mathrm{a}^{-1}$, and drainage and refill events generally occurring where surface velocities were $>8.0 \mathrm{~m} \mathrm{a}^{-1}$ (Fig. 7). Furthermore, comparatively higher surface velocities on G1 in 2018 (Fig. 7) corresponds with a decline in both the number and area of supraglacial ponds across the whole glacier (Table 1, Fig. 4), suggesting velocity may play a key role in pond formation and decay here. Ponds with multiple drainage events were associated with substantially higher ice velocities, which would facilitate englacial conduit opening. As such, surface velocities appear to be an important control on pond drainage and persistence on our glaciers, with drainage generally occurring in areas with velocities above $8.0 \mathrm{~m} \mathrm{a}^{-1}$.

\subsubsection{Pond G3-A}

Pond G3-A behaved differently than the other supraglacial ponds on G3 as the ponded area was higher during the monsoon season than in any other season. This contrasts with our other observations, where ponded area generally decreased during the monsoon season. We observed no drainage events at pond G3-A during the study period, with the only drainage occurring via an established outlet channel that connects to the proglacial environment. The lack of observed drainage events and continuous filling indicates that pond G3-A has no efficient connection to the englacial system and/or is at or below hydrological base level, allowing for continued expansion (e.g. Quincey and others, 2007; Benn and others, 2012; Mertes and others, 2016; Thompson and others, 2016). There is a possibility based on the consistent expansion observed here that G3 may develop into a proglacial lake in the future (Richardson and Reynolds, 2000; Bolch and others, 2008). However, we refrain from speculating here as it may lead to misinformation. Instead, we recommend the pond be closely monitored to forecast future risks to downstream populations, including area and hydrological changes of the pond itself, as well as structural changes at the glacier terminus moraines.

\subsection{Ice cliffs}

\subsubsection{Ice cliff distribution}

The majority of cliffs were located between the glacier termini and the mid-ablation area, as with the supraglacial ponds (Fig. S8). This spatial distribution mirrors that in the Everest region (e.g. Watson and others, 2017a; Steiner and others, 2019), and remains similar throughout the year, suggesting that seasonal-scale controls have less impact on ice cliffs than they do on ponds. Ice cliffs form due to the slope steepening past the angle of repose or through englacial roof collapse (e.g. Kirkbride, 1993; Sakai and others, 2000; Reid and Brock, 2014). We might therefore expect to find cliffs in both faster-flowing ice, due to crevassing and thus slope steepening, and slower-flowing ice, due to pond expansion and subsequent englacial collapse. However, we found no clear association between ice cliffs and surface velocities, with cliffs existing at a range of glacier surface velocities (Fig. 7 and Fig. S8). Notably, in slow-flowing zones $\left(<4.0 \mathrm{~m} \mathrm{a}^{-1}\right)$ ice cliffs continued to form and decay, potentially through conduit collapse. This suggests that surface velocities have a limited influence on the location of ice cliffs on our glaciers, in contrast to their influence on pond locations.

\subsubsection{Spatial coincidence of ice cliffs and supraglacial ponds} Recent studies indicate that ice cliffs and supraglacial ponds tend to form in the same locations and due to the same controlling factors (e.g. Watson and others, 2017a; Steiner and others, 2019). However, our data show that of the total number of supraglacial ponds, only $19.0 \%$ coincided with an ice cliff which is markedly lower than other regions of the Himalaya, with estimates for the Everest region ranging between 49.0 and $74.0 \%$ of the total pond number (Thompson and others, 2016; Watson and others, 2017a). One potential explanation may be the rapid rates of pond expansion and high frequency of drainage events observed in our study, which could indicate that ponds associated with ice cliffs can grow and drain so quickly that our roughly monthly resolution misses these filling events. Alternatively, ice cliffs with no neighbouring pond may have been exposed as a result of surface debris redistribution, and therefore formed without the influence of any supraglacial ponding (Sakai and others, 1998; Watson and others, 2017a). To differentiate between these two mechanisms, very high temporal and spatial resolution data would be required. The percentage of ice cliffs with coincident ponds was consistently higher during the monsoon period than in any other period, as previously noted in the Langtang region (Steiner and others, 2019). A likely explanation for this is that the number of supraglacial ponds typically increases during the summer melt season as meltwater supply increases and topographic hollows are 'activated' (e.g. Watson and others, 2016), making it more likely that ponds will intersect with ice cliffs.

\section{Conclusions}

This paper presented the first high-resolution, remotely sensed assessment of supraglacial ponds and ice cliffs for three debriscovered glaciers in Bhutan. Our results showed substantial spatial and temporal variations in the number and area of ponds, and highlighted differences on individual glaciers and between glaciers. Maximum ponded area occurred in the monsoon season, likely due to increased meltwater and precipitation. Increases in ponded area on G2 and G3 during the winter season may indicate efficient removal of surplus meltwater approaching winter, before ponds become 'inactive'. Pond drainage occurred throughout the year, but was most frequent during the monsoon season, which we attribute to increasing englacial efficiency during the summer and increased meltwater facilitating conduit collapse and pond drainage. Sporadic drainage events outside of the monsoon season may indicate that the englacial hydrological system remains active throughout the year, irrespective of season. The lack of drainage events on the lower ablation zone of both G1 and G3, coupled with the increased ponded area and lower glacier velocities, may indicate ponds on both glaciers could coalesce in the lower ablation areas, and should be monitored closely. Furthermore, we 
observed an increase of $88 \%$ in the area of pond G3-A and no drainage events. This may suggest pond G3-A is at the base level and thus is likely to continue to expand.

Ice velocities appear to control pond locations, with ponding being prevalent in areas $<8 \mathrm{~m} \mathrm{a}^{-1}$. However, the spatial pattern of ponding on G1 also highlights the role of local topography in governing pond dynamics and hence patterns of ice loss. While a key control for pond development, we found no clear association between surface velocities and ice cliff development. Only a small percentage of the total number of ponds had an adjacent ice cliff $(19.0 \%)$ which is considerably lower than that in the Khumbu ( 49.0\%) and Langtang ( 58-69\%) regions (Miles and others, 2016; Watson and others, 2017a, b). We suggest this reflects the high frequency of drainage events, which leave ice cliffs without an associated pond. A higher temporal resolution may thus be required in order to capture the full extent of drainage and refill events. The high number of drainage events outside of the monsoon season, coupled with pond persistence throughout the year indicates that supraglacial ponds may continue to drain, fill and coalesce. Thus, continued monitoring of these glaciers, along with others in the region, is vital for future hazard assessments.

Supplementary material. The supplementary material for this article can be found at https://doi.org/10.1017/jog.2021.76.

Acknowledgements. We acknowledge two freely available datasets used in this study; Planet Labs from which the satellite imagery was obtained, and the Randolph Glacier Inventory (GLIMS Glacier Database) for the glacier shapefiles. We are also grateful to Amaury Dehecq for supplying us with the velocity data.

Conflict of interest. The authors declare that the research was conducted in the absence of any commercial or financial relationships that could be construed as a potential conflict of interest.

\section{References}

Barnett TP, Adam JC and Lettenmaier DP (2005) Potential impacts of a warming climate on water availability in snow-dominated regions. Nature 438(7066), 303-309.

Benn DI and 9 others (2012) Response of debris-covered glaciers in the Mount Everest region to recent warming and implications for outburst flood hazards. Earth-Science Reviews 114, 156-174.

Benn DI and 5 others (2017) Structure and evolution of the drainage system of a Himalayan debris-covered glacier and its relationship with patterns of mass loss. The Cryosphere 11, 2247-2264.

Benn DI, Wiseman S and Hands KA (2001) Growth and drainage of supraglacial lakes on debris-mantled Ngozumpa Glacier Khumbu Himal Nepal. Journal of Glaciology 47(159), 626-638.

Bolch T, Buchroithner MF, Peters J, Baessler M and Bajracharya S (2008) Identification of glacier motion and potentially dangerous glacial lakes in the Mt. Everest region/Nepal using spaceborne imagery. Natural Hazards and Earth System Sciences 8, 1329-1340.

Bolch T, Pieczonka T and Benn DI (2011) Multi-decadal mass loss of glaciers in the Everest area (Nepal Himalaya) derived from stereo imagery. The Cryosphere 5(2), 349-358.

Bookhagen B and Burbank DW (2010) Toward a complete Himalayan hydrological budget: spatiotemporal distribution of snowmelt and rainfall and their impact on river discharge. Journal of Geophysical ResearchEarth 115(F3).

Brun F and 9 others (2018) Ice cliff contribution to the tongue-wide ablation of Changri Nup glacier Nepal central Himalaya. The Cryosphere 12(11), 3439-3457.

Buri P and 5 others (2016a) A physically-based 3D-model of ice cliff evolution over debris-covered glaciers. Journal of Geophysical Research-Earth 121 (12), 2471-2493.

Carrivick JL and Tweed FS (2016) A global assessment of the societal impacts of glacier outburst floods. Global Planet Change 144, 1-16.
Cooley S, Smith L, Stepan L and Mascaro J (2017) Tracking dynamic northern surface water changes with high-frequency planet CubeSat imagery. Remote Sensing 9(12), 1306.

Dorji U, Olesen JE, Bøcher PK and Seidenkrantz MS (2016) Spatial variation of temperature and precipitation in Bhutan and links to vegetation and land cover. Mountain Research and Development 36(1), 66-80.

Gardner AS and 6 others (2018) Increased West Antarctic and unchanged East Antarctic ice discharge over the last 7 years. The Cryosphere 12(2), 521-547. doi: 105194/tc-12-521-2018.

Gardner AS, Fahnestock MA and Scambos TA (2019) ITS_LIVE Regional Glacier and Ice Sheet Surface Velocities Data archived at National Snow and Ice Data Center; doi:105067/6II6VW8LLWJ7.

Herreid S and Pellicciotti F (2018) Automated detection of ice cliffs within supraglacial debris cover. The Cryosphere 12(5), 1811-1829.

Hoy A, Katel O, Thapa P, Dendup N and Matschullat J (2016) Climatic changes and their impact on socio-economic sectors in the Bhutan Himalayas: an implementation strategy. Regional Environmental Change 16(5), 1401-1415.

Huss M and Hock R (2018) Global-scale hydrological response to future glacier mass loss. Nature Climate Change 8(2), 135-140.

Irvine-Fynn TD and 8 others (2017) Supraglacial ponds regulate runoff from Himalayan debris-covered glaciers. Geophysical Research Letters 44(23), 11894.

Jordan RE and Stark JA (2001) Capillary tension in rotting ice layers (No. ERDC/CRREL-TR-01-13) Engineer Research and Development Center, Hanover, NH, Cold Regions Research and Engineering Lab.

Karma T and KB and Taman (1999) Preliminary Report of Tshokar Tsho in the Head Waters of Chamkhar Chu Bhutan. Geological Survey of Bhutan Thimphu.

King O, Bhattacharya A, Bhambri R and Bolch T (2019) Glacial lakes exacerbate Himalayan glacier mass loss. Scientific Reports-UK 9(1), 1-9.

Kirkbride MP (1993) The temporal significance of transitions from melting to calving termini at glaciers in the central Southern Alps of New Zealand. The Holocene 3(3), 232-240.

Kraaijenbrink PDA, Shea JM, Pellicciotti F, De Jong SM and Immerzeel WW (2016) Object-based analysis of unmanned aerial vehicle imagery to map and characterise surface features on a debris-covered glacier. Remote Sensing of Environment 186, 581-595.

Li X and 9 others (2008) Cryospheric change in China. Global Planet Change 62(3-4), 210-218.

Maurer JM, Schaefer JM, Rupper S and Corley A (2019) Acceleration of ice loss across the Himalayas over the past 40 years. Science Advances 5(6), eaav7266.

McFeeters SK (1996) The use of the normalized difference water index (NDWI) in the delineation of open water features. International Journal of Remote Sensing 17(7), 1425-1432.

Mertes JR, Thompson SS, Booth AD, Gulley JD and Benn DI (2016) A conceptual model of supra-glacial lake formation on debris-covered glaciers based on GPR facies analysis. Earth Surface Processes 42(6), 903-914.

Miles ES and 6 others (2017) Pond dynamics and supraglacial-englacial connectivity on debris-covered Lirung glacier Nepal. Frontiers in Earth Science 5(69).

Miles ES, Willis IC, Arnold NS, Steiner J and Pellicciotti F (2016) Spatial seasonal and interannual variability of supraglacial ponds in the Langtang Valley of Nepal 1999-2013. Journal of Glaciology 63(237), 88-105.

Mool PK and 5 others (2001) Inventory of glaciers glacial lakes and glacial lake outburst floods Monitoring and early warning systems in the Hindu Kush-Himalayan Region: Bhutan Inventory of glaciers glacial lakes and glacial lake outburst floods Monitoring and early warning systems in the Hindu Kush-Himalayan Region: Bhutan.

Narama C and 6 others (2017) Seasonal drainage of supraglacial lakes on debris-covered glaciers in the Tien Shan Mountains Central Asia. Geomorphology 286, 133-142.

Nie Y and 10 others (2021) Glacial change and hydrological implications in the Himalaya and Karakoram. Nature Reviews Earth \& Environment 2(2), 91-106. doi: 10.1038/s43017-020-00124-w.

Östrem G (1959) Ice melting under a thin layer of moraine and the existence of ice cores in moraine ridges. Geografiska Annaler 41(4), 228-230.

Otsu N (1979) A threshold selection method from gray-level histograms. IEEE Transactions on Systems, Man, and Cybernetics 9(1), 2-66.

Pritchard HD (2019) Asias shrinking glaciers protect large populations from drought stress. Nature 569, 649-654.

Quincey DJ, Richardson SD, Luckman A, Lucas RM, Reynolds JM, Hambrey MJ and Glasser NF (2007) Early recognition of glacial lake 
hazards in the Himalaya using remote sensing datasets. Global and Planetary Change 56(1-2), 137-152.

Reid TD and Brock BW (2014) Assessing ice-cliff backwasting and its contribution to total ablation of debris-covered Miage glacier Mont Blanc massif Italy. Journal of Glaciology 60(219), 3-13.

Reynolds JM (2000) On the formation of supraglacial lakes on debris-covered glacier debris-covered glaciers. IAHS-AISH P 264, 153-164.

RGI Consortium (2017) Randolph Glacier Inventory - A Dataset of Global Glacier Outlines: Version 60: Technical Report Global Land Ice Measurements from Space Colorado USA.

Richardson SD and Reynolds JM (2000) An overview of glacial hazards in the Himalayas. Quaternary International 65-66, 31-47.

Rounce DR, Hock R and Shean DE (2020) Glacier mass change in high mountain Asia through 2100 using the open-source python glacier evolution model (PyGEM). Frontiers in Earth Science 7, 331

Rounce D and 10 others (in review) Distributed debris thickness estimates of all debris-covered glaciers on earth. Geophysical Research Letters

Sakai A, Nakawo M and Fujita K (1998) Melt rate of ice cliffs on the Lirung glacier Nepal Himalayas 1996. Bulletin of Glacier Research 16, 57-66.

Sakai A, Takeuchi N, Fujita K and Nakawo M (2000) Role of supraglacial ponds in the ablation process of a debris-covered glacier in the Nepal Himalayas. IAHS-AISH P 265, 119-132.

Salerno F and 6 others (2012) Glacial lake distribution in the Mount Everest region: uncertainty of measurement and conditions of formation. Global Planet Change 92, 30-39.

Shean D (2017) High Mountain Asia 8-meter DEM Mosaics Derived from Optical Imagery, Version 1. Boulder, Colorado USA. NASA National Snow and Ice Data Center Distributed Active Archive Center. doi: https:// doi.org/10.5067/KXOVQ9L172S2. [01/02/2021].

Shean DE and 5 others (2020) A systematic regional assessment of High Mountain Asia glacier mass balance. Frontiers in Earth Science 7, 363.

Shugar DH and 9 others (2020) Rapid worldwide growth of glacial lakes since 1990. Nature Climate Change 10, 939-945.
Steiner JF and 5 others (2015) Modelling ice-cliff backwasting on a debriscovered glacier in the Nepalese Himalaya. Journal of Glaciology 61(229), 889-907.

Steiner JF, Buri P, Miles ES, Ragettli S and Pellicciotti F (2019) Supraglacial ice cliffs and ponds on debris-covered glaciers: spatio-temporal distribution and characteristics. Journal of Glaciology 65(252), 617-632.

Thompson SS, Benn DI, Dennis K and Luckman A (2012) A rapidly growing moraine-dammed glacial lake on Ngozumpa glacier Nepal. Geomorphology $145,1-11$.

Thompson S, Benn DI, Mertes J and Luckman A (2016) Stagnation and mass loss on a Himalayan debris-covered glacier: processes patterns and rates. Journal of Glaciology 62(233), 467-485.

Wagnon P and 11 others (2013) Seasonal and annual mass balances of Mera and Pokalde glaciers (Nepal Himalaya) since 2007. The Cryosphere 7(6), 1769-1786.

Wang X, Liu SY, Han HD, Wang J and Liu Q (2012) Thermal regime of a supraglacial lake on the debris-covered Koxkar Glacier southwest Tianshan China. Environmental Earth Sciences 67(1), 175-183.

Wang X, Siegert F, Zhou AG and Franke J (2013) Glacier and glacial lake changes and their relationship in the context of climate change central Tibetan plateau 1972-2010. Global and Planetary Change 111, 246-257.

Watson CS and 5 others (2017b) Heterogeneous water storage and thermal regime of supraglacial ponds on debris-covered glaciers. Earth Surface Processes 43(1), 229-241.

Watson CS, Quincey DJ, Carrivick JL and Smith MW (2016) The dynamics of supraglacial ponds in the Everest region central Himalaya. Global Planet Change 142(Supplement C), 14-27.

Watson CS, Quincey DJ, Carrivick JL and Smith MW (2017a) Ice cliff dynamics in the Everest region of the Central Himalaya. Geomorphology 278, 238-251.

Watson CS, King O, Miles ES and Quincey DJ (2018) Optimising NDWI supraglacial pond classification on Himalayan debris-covered glaciers. Remote Sensing of Environment 217, 414-425. 